\title{
The Role of Psychological Capital in predicting Work-Family Conflict
}

\author{
Rusmalia Dewi ${ }^{1 *}$, Joniarto Parung ${ }^{2}$, Artiawati $^{3}$ \\ ${ }^{1}$ Psychology Doctoral Program, University of Surabaya, Indonesia \\ ${ }^{2}$ Psychology Doctoral Program, University of Surabaya, Indonesia \\ ${ }^{3}$ Psychology Doctoral Program, University of Surabaya, Indonesia \\ *Corresponding author. Email: liadewi7457@gmail.com
}

\begin{abstract}
Research on psychological capital and work-family conflict has shown mixed results. Several studies have shown a high correlation between results and a low one. In theory, psychological capital should be able to become an individual's psychological resource in reducing work-family conflicts. Research on psychological capital with work-family conflict in Medical Representative is also rarely conducted, so further studies are needed in order to reduce work-family conflict in Medical Representative. Two domains of adult needs that demand fulfillment in order to balance the two, namely work and family. If one domain has a problem, it will affect the other domains, because these two domains are interconnected. Conditions like this can be a workfamily conflict that can occur in working adult spouses. Data for the last ten years shows that working spouses are increasing, so the potential for work-family conflicts for working partners will also increase. The potential for work-family conflicts tends to increase in cases with long and unscheduled working hours, for example to medical representatives (Medical Representative). This study aims to examine the relationship between psychological capital and work-family conflict in Medical Representative. This study used 168 Medical Representative respondents. The mean age was $18-29$ years ( $\mathrm{SD}=8,98)$ with $47,62 \%$ female and 52,38\% male. The work-family conflict scale is Carlson's standard measurement tool adapted by Artiawati from Indonesia. The psychological capital scale uses a scale from Luthans. The simultaneous results on multiple linear regression analysis showed that psychological capital had a significant relationship with work-family conflict $(\mathrm{F}=4,434 \mathrm{p}$ $<0.037)$. Resilience predicted the strongest $(\beta=-0.689 \mathrm{p}<0.01)$ compared to the other three dimensions of psychological capital on work-family conflict in Medical Representative. This means that the dimensions of psychological capital cannot play a good role if there is no resilience. Further research can add other positive variables that are predicted to reduce work-family conflicts, such as work-family climate and meaningfulness of work.
\end{abstract}

Keywords: Medical representative, psychological capital, work-family conflict.

\section{INTRODUCTION}

Working adults have two domains that demand fulfillment and responsibility for both. The two domains are the work domain and the family domain. If a problem occurs in one domain, it will affect other domains. This is because the two domains are interconnected and influence each other. This imbalance in fulfillment can lead to work-family conflicts. The topic of work-family conflicts among working partners is now getting more and more attention. An important problem experienced by working partners is to find the balance between work life and family life [1]. Data on working partners for the last ten years taken from America, Canada and Indonesia shows that it is increasing every year, with a figure of around $60 \%$ $80 \%$ [2, 3, 4]. Many working partners experience work-family conflicts, one of which is a medical representative.

Medical Representative has duties as a representative for a pharmaceutical company and works as a marketing agent for health service 
providers such as doctors, pharmacists and midwives. Medical Representative is in charge of providing health information about the products being sold and influencing health care providers to use their products [5]. Medical Representative's duties and responsibilities in achieving the company's targets are very complex, such as the achievement of the target daily visits to doctors, pharmacies and also the achievement of daily targets for product orders promoted and can act as a salesman. This takes up Medical Representative's time and energy in carrying out its obligations in the company, on the other hand Medical Representative also has the duty and responsibility to meet the needs of his family. High work demands can increase work-family conflict and reduce family fulfillment. The problem that can arise in the family is the lack of time together with the family. In Indonesia, which adopts a collectivism culture, the expected togetherness is not only for the nuclear family but also for the extended family. For working couples who have children, the level of work-family role conflict in working partners is higher than those without children, so that many working partners try to balance work-family life [6][7]. Work-family conflict is a form of pressure or demands from both the work domain and the family domain and is reciprocal and influences each other [8].

Work-family conflict is the existence of demands or pressures from either the work or family domain, this can make the responsibilities in these two domains mutually influence the fulfillment of the needs of one domain against the other [8]. This pressure or demand can be in the form of a longer time given to one domain so that it affects other domains. The existence of pressure or demands due to the tension brought from the work domain affects the family domain and vice versa. Work-family conflict, if not managed properly, can cause serious problems. The results of the study Cooklin [9] show that work-family conflict can reduce mental health conditions in working partners and having children. This is supported by the results of research by Zhou et al [10], which also emphasizes the consequences of work-family conflict on physical and mental health and individual happiness at work, but there is still little that explains the psychological process regarding the effects of work-family conflict on health.

Health, happiness can be felt when work-family conflicts can be controlled. One of them is with psychological capital being able to reduce or manage work-family conflicts so that work-family balance is achieved. Several studies on psychological capital state that psychological capital is negatively correlated and is a supportive factor in supporting working partners to reduce work-family conflicts [11][12][13]. Psychological capital is an individual psychological condition that develops positively characterized by having four components such as self-confidence, hope, resilience and optimism [14]. Individuals who have high psychological capital will have a lot of positive emotions such as high selfconfidence, have clear goals for the future in their work and family life, have a strong belief in the process of achieving goals and when faced with difficulties, they will quickly rise up and solve existing problems so that able to reduce work-family conflict [15].

Research on the role of psychological capital in predicting work-family conflict in Medical Representative in Indonesia, so far, still requires further study. Some psychological capital studies mostly use the subject of teachers, nurses, bank employees, entrepreneurs, millennial generation children, the media, athletes and students. The interest in doing research on Medical Representative is because the duties and responsibilities of Medical Representative at work are full of pressure or demands, long working hours and family responsibilities that make Medical Representative struggle to reduce work-family conflicts in order to balance work-family life. Several studies state that psychological capital is a positive resource that can improve employee performance, work commitment, employee welfare over time, employee stress and employee turnover [16][17].

Individuals use psychological capital to deal with the constant conflict between work and family. Excessive work demands result in a work fatigue, which in turn can affect relationships with family. Increasing psychological capital can reduce workfamily conflicts, one of which is reducing work fatigue [18]. Medical Representatives with the duties and responsibilities that are carried out at work and on the other hand carrying out duties and responsibilities in the family if one of them is not fulfilled their needs will greatly increase workfamily conflict. The rapid development of the pharmaceutical market with intense competition in the pharmaceutical world has made Medical Representative have to fight hard to achieve the company's targets. The target that increases every year is the length of Medical Representative time at work, such as a few days a month doing out-of-town assignments which results in reducing Medical Representative time with family. This can be the cause of the increased pressure that the Medical 
Representative experiences at work. On the other hand, it can affect the responsibility and time that should be given to the family, thus requiring positive psychological capital from within the individual. The role of psychological capital such as selfefficacy, hope, resilience and optimism is important in reducing or managing the work-family conflict Medical Representative. This means that Medical Representative with high psychological capital can carry out its duties confidently, is able to make clear work goals in the future so that it can carry out the tasks given by the company with full confidence and be able to face difficulties. Medical Representative has short- and long-term goals and understands the steps that must be taken. Medical Representative is full of enthusiasm in doing all the tasks given by the company and when in a difficult situation Medical Representative is able to quickly get back up and has a high fighting power in solving the problems at hand.

In theory and several studies that have been done support that psychological capital is a structure that includes positive results that can be used to improve individual performance both personally and at the organizational level. Psychological capital can be measured, developed and managed effectively to improve job performance [19]. This psychological theory-based research is a "high-level core construction that includes four positive psychological resources" consisting of self-efficacy, hope, resilience and optimism.

Research by Schulz [20] found that psychological capital is positively correlated with job satisfaction and organizational commitment and has a negative correlation with the desire to change jobs. Research by Sabokro [21] explains that psychological capital has a significant negative relationship to work-family conflict and family-work conflict. Karatepe \& Karadas research explains that psychological capital is able to predict work-family conflict and work-family conflict as well as the desire to leave work and employee absence from work

Some of the studies above explain that psychological capital has a relationship with workfamily conflicts with various research contexts such as truck drivers, nurses, banking employees and so on. The present study examines the relationship between psychological capital and work-family conflict at Medical Representative. The hypothesis in this study is: there is a relationship between psychological capital and work-family conflict. Where the purpose of this study is to examine the role of psychological capital in predicting workfamily conflict in Medical Representative.

\section{METHOD}

\subsection{Research Subject}

This research was conducted as a preliminary study on research on work-family conflict at Medical Representative. 168 Medical Representative samples were taken accidentally. The criteria are already married and both are working partners. The mean age was $18-29$ years $(\mathrm{SD}=8,98)$ with $47,62 \%$ female and $52,38 \%$ male.

\subsection{Research Instruments}

The Work Family Conflict (WFC) scale from Carlson adapted in Indonesian by Artiawati, consists of 12 items. There are 4 constructs in it, namely strain based on work interference family, time based on work interference family, strain based on family interference work and time based on family interference work. Scoring scales between strongly disagree (1), disagree (2), slightly disagree (3), somewhat agree (4), agree (5) and strongly agree (6). The higher the score obtained, the higher the level of work-family conflict and vice versa. Reliability of the research scale is $\alpha=0.874$.

Psychological capital, consisting of 4 dimensions, namely self-efficacy, hope, resilience and optimism from Luthans, consists of 24 items. The scoring scale is between strongly disagree (1), disagree (2), slightly disagree (3), somewhat agree (4), agree (5) and strongly agree (6). The higher the score obtained, the higher the psychological capital owned and vice versa. This scale has a high value of Cronbach's Alpha $(\alpha=0.884)$.

\subsection{Procedure}

Participants were given a questionnaire while waiting for a doctor either at the hospital or at the practice. Survey participants were instructed to complete the questionnaire independently and return the questionnaire to the researcher. Participants in the study were volunteers with anonymous or anonymous identities.

\section{RESULTS}

This study used multiple linear regression analysis with the SPSS21 program. Where this statistical technique is able to predict the relationship between the independent variable $(x)$ and the dependent variable (y). 
The results, as presented in in Table 1., showed that $\mathrm{F}$ value $=4.434 \mathrm{p}<0.037$ indicates the simultaneous influence of psychological capital on work-family conflict.

Table 1. Results of Regression Analysis

\begin{tabular}{|c|c|c|}
\hline Variable & F & Sig \\
\hline $\begin{array}{c}\text { Work-Family Conflict } \\
\text { (DV) }\end{array}$ & 4,434 & 0,037 \\
\hline $\begin{array}{c}\text { Psychological Capital } \\
\text { (IV) }\end{array}$ & - & - \\
\hline
\end{tabular}

The average age of the participants was 18-29 years $(48 \%), 30-39$ years old $(37.5 \%), 40-49$ years old $(10 \%)$, 50-59 years old $(4.5 \%)$. On average, participants had between 1-3 children (50\%) and no children (50\%). High school education (23.8\%), adjusted high school (9.5\%), diploma (30.4\%), bachelor degree $(36.3 \%)$. The status of PMDN companies $(48.2 \%)$, PMA $(13.7 \%)$ and BUMN $(10.7 \%)$ and the rest were not detected $(27.4 \%)$.

The intercorrelation value, as shown in Table 2 ., was -0.16 , which indicated that psychological capital has a significant negative relationship with workfamily conflict by $16 \% \mathrm{p}<0.05$.

Table 2. Mean, SD and intercorrelation

\begin{tabular}{|l|c|c|c|c|}
\hline \multicolumn{1}{|c|}{ Variabel } & Mean & SD & 1 & 2 \\
\hline $\begin{array}{l}\text { 1.Work-Family } \\
\text { Conflict }\end{array}$ & 51,04 & 15,05 & - & - \\
\hline $\begin{array}{l}\text { 2.Psychological } \\
\text { Capital }\end{array}$ & 100,21 & 19,01 & - & - \\
\hline
\end{tabular}

$* \mathrm{p}<0,05$

In Table 3, partially this study shows that the role of resilience has become the most significant factor in influencing work family conflicts with a value of $\beta=-0.69 \mathrm{p}<0.01$ meaning that resilience has a significant negative correlation to work-family conflict, compared to the other three dimensions. The other three dimensions of psychological capital, namely self-efficacy, hope and optimism do not have a significant correlation with work-family conflict.

Table 3. Stepwise Regression Analysis

\begin{tabular}{|l|c|c|c|}
\hline \multicolumn{1}{|c|}{ Variables } & $\mathrm{B}$ & $\mathrm{t}$ & Sig. \\
\hline Resilience & $-0,69$ & $-2,62$ & $0,01^{* *}$ \\
\hline Self Efficacy & $-0,06$ & $-0,77$ & 0,44 \\
\hline
\end{tabular}

\begin{tabular}{|l|c|c|c|}
\hline Hope & 0,71 & 0,75 & 0,45 \\
\hline Optimism & 0,05 & 0,53 & 0,59 \\
\hline
\end{tabular}

Dependent Variable: Work-Family Conflict

Sig. $\mathrm{p}<0,01 * *, \mathrm{p}<0,05^{*}$

The overall results explain that the four dimensions or said to be psychological capital have a significant negative correlation to work-family conflict but partially only resilience has a significant negative effect on work-family conflict and the other three dimensions do not.

\subsection{Discussion}

The results of this study indicate that psychological capital has a significant correlation with work-family conflict. Together, the four components of psychological capital, such as selfefficacy, hope, resilience and optimism, have a significant relationship to work-family conflict. On the other hand, it turns out that only resilience has the greatest influence compared to the other three dimensions in predicting work-family conflict. This explains that resilience is important in explaining the relationship with work-family conflict variables.

The dimensions of psychological capital have their respective roles in the individual. The selfefficacy dimension means that individuals have confidence in carrying out the tasks given by the company so that individuals feel confident that they are able to carry out tasks filled with these challenges. The second dimension is optimism, where individuals get enthusiasm and positive beliefs about the goals that are now achieved will be related to future achievements. This relates to the next dimension, namely hope, where individuals proceed in carrying out their goals in the future. Every process that is undertaken can run smoothly or not. It takes an individual alacrity in evaluating his work plans whether they are in accordance with the objectives to be achieved, if needed, individuals can change their work plans so that they can be adjusted to the goals to be achieved. The fifth dimension is resilience; individuals when facing difficulties or problems are able to survive and can immediately rise to solve the problem in order to achieve the desired success [22].

Of all the dimensions of psychological capital, resilience is the strongest predictor so that resilience needs to come together in explaining work-family conflicts.

A qualitative study of the resilience of nurses who care for people towards the end of their lives, 
found that they are quite in conflict with their families due to caring for patients who are brought home so that resilience is needed for nurses to be able to balance work life with family [23]. Furthermore, Bande et al [24] research on marketing or salespeople found that emotional intelligence and resilience have an influence on the desire to change jobs through work-family conflicts. thus developing emotional skills and resilience are needed in order to reduce work-family conflicts and the desire to change employee jobs. Lanz's [25] research states that nurses need resilience to be able to manage tension and stress so that they do not cause further effects at work such as the desire to move, work fatigue, job satisfaction and work injuries. Research by Macphee et al [26] also states that resilience is needed to quickly build a family's balance due to previous disturbances or difficulties.

Some of the studies above can state that the role of resilience is needed to be able to quickly return individuals from conditions that are full of tension, imbalance, difficulty and full of disturbances to a state of balance in work and family life. This balance can make individuals happier in life and mentally healthier so that they can work well and do not cause emotional fatigue, or the desire to quit work. Likewise what happened to Medical Representative, the existence of pressure at work such as daily targets from sales or visits to doctors, pharmacies or hospitals, unclear roles, long hours at work, all of which can disturb the balance of work and family.

Medical Representative resilience is needed in order to solve problems as quickly as possible in order to balance work-family life and be able to work effectively so as to improve performance in the company.

The role of resilience together with the other three dimensions, namely self-efficacy, hope and optimism, can simultaneously predict work-family conflicts as well as family-work conflicts. Supported by research by Sabokro on nurses, they found that psychological capital has a significant negative correlation with work-family conflict and familywork conflict. Karatepe and Karadas research on frontline hospitality employees found that psychological capital has a significant negative effect on work-family conflict and family-work conflict. It is in line with this research that psychological capital has a significant negative effect on work-family conflict and Medical Representative family-work conflict. Overall, it can be said that psychological capital is able to predict work-family conflict at Medical Representative.

\subsection{Conclusion and limitations}

Psychological capital has a significant relationship with work-family conflict and resilience is the strongest predictor of explaining work-family conflict. This means that without resilience, other dimensions such as self-efficacy, hope and optimism cannot be used together to explain the dynamics of work-family conflicts.

The limitation of this study is that this study does not limit the presence or absence of children. In fact, the care of children under the age of 21 who live with their parents has considerable conflict in each of their developmental phases. Children are still completely dependent on their parents and adolescence is a vulnerable period, children have a lot of conflicts in relationships with peers so they need support from their parents [27][28]. Based on this theoretical reference, the criteria for the age of the child and the number of children living with their parents greatly influence the results of this study so that further research needs to include the criteria for the age of the child and the number of children in the family living together. Recommendations for further research, it is better to pay attention to the age of children living with parents so that it can explain the level of work-family conflict faced by parents.

\section{AUTHORS' CONTRIBUTIONS}

RD made the idea, collected and analyzed the data, wrote and completed the article. JP and A helped analyzing the data and discussion. A provided the measurement tool.

\section{ACKNOWLEGDEMENTS}

This research is really a preliminary research for my dissertation and has never been published anywhere. I thank Prof. Joniarto Parung and Mrs. Artiawati for guiding and providing advice on the content of my article.

\section{REFERENCES}

[1] H. Puspitawati, M. Simanjuntak, L. Hayati. Kontribusi ekonomi dan peran ganda perempuan serta pengaruhnya terhadap kesejahteraan subjektif. J. Ilmu Keluarga Konsumen 5(1) (2012) 11-18). DOI: 10.24156/jikk.2012.5.1.11

[2] Data Statistik Amerika, 2020. https:// 
www.statista.com/statistics/269959/employme nt-in-the-united-states/

[3] Data Statistik Kanada, 2019. https:// www.statista.com/statistics/464156/numberof-full-time-workers-incanada/\#: :text=This\%20statistic $\% 20$ shows $\%$ 20the $\% 20$ total,full $\% 2$ Dtime $\% 20$ basis $\% 20 \mathrm{in} \%$ 20Canada.

[4] N. Midayati. Keadaan ketenagakerjaan Indonesia Februari 2018. Berita Resmi Statistik 42 (2018) pp.1-16

[5] H. L. Thu. Exploring medical representatives' strategies to influence doctors' prescribing decisions in Vietnam. Department of Public Health and Clinical Medicine. 2012. pp. 37-39.

[6] A. Shimazu, K. Kubota, A.B. Bakker, E. Demerouti, K. Shimada, N. Kawakami. Workto-family conflict among Japanese dual-earner couples with preschool children: A spillovercrossover perspective. J. Occup. Health 55 (2013) 234-243

[7] D. Yucel, B.A. Latshaw. Spillover and crossover effects of work-family conflict among married and cohabiting couples. Soc. Ment. Health 10(1) (2020) 35-60 DOI: $10.1177 / 2156869318813006$

[8] M.R. Frone, M. Russell, M.L. Cooper. Antecedents and outcomes of work-family conflict: Testing a model of the work-family interface. J. Appl. Psychol. 77(1) (1992) 6578. DOI: 10.1037/0021-9010.77.1.65

[9] A.R. Cooklin, H. Dinh, L. Strazdins, E. Westrupp, L. S. Leach, J. M. Nicholson. Change and stability in work-family conflict and mothers' and fathers' mental health: Longitudinal evidence from an Australian cohort. Soc. Sci. Med. 155 (2016) 24-34. DOI: 10.1016/j.socscimed.2016.02.036

[10] S. Zhou, S. Da, H. Guo, X. Zhang. Workfamily conflict and mental health among female employees: A sequential mediation model via negative affect and perceived stress. Front. Psychol. 9 (2018) DOI: 10.3389/fppsyg.2018.00544

[11] J.B. Avey, F. Luthans, R.M. Smith, N.F. Palmer. Impact of positive psychological capital on employee well-being over time. $J$. Occup. Health Psychol. 15(1) (2010) 17-28 DOI: $10.1037 / \mathrm{a} 0016998$

[12] O.M. Karatepe, G. Karadas. The effect of psychological capital on conflicts in the workfamily interface, turnover and absence intentions. Int. J. Hosp. Manag. 43 (2014) 132-143 DOI: 10.1016/j.ijhm.2014.09.005

[13] M. Zhang, R.W. Griffeth, D.D. Fried. Workfamily conflict and individual consequences. $J$. Manag. Psychol. 27(7) (2012) 696-713 DOI: $10.1108 / 02683941211259520$

[14] F. Luthans, C.M. Youssef-Morgan. Psychological capital: An evidence-based positive approach. Annu. Rev. Organ. Psychol. 4 (2017) 339-366. DOI: 10.1146/annurevorgpsych-032516-113324

[15] T. Brandt, J.F.S. Gomes, D. Boyanova. Personality and psychological capital as indicators of future job success? A multicultural comparison between three European countries. Finn. J. Bus. Econ. 3(11), (2011) 263-289

[16] J.B. Avey, F. Luthans, C.M. Youssef. The additive value of positive psychological capital in predicting work attitudes and behaviors. $J$. Manag. 36(2) (2010) 430-452. DOI: $10.1177 / 0149206308329961$

[17] H. Luo, Z. H. Hao. The relationships among psychological capital, job burnout and turnover intention in 466 nurses. Chin J Nurs 45 (2010) 93-95

[18] J. Pu, H. Hou, R. Ma, J. Sang. The effect of psychological capital between work-family conflict and job burnout in Chinese university teachers: Testing for mediation and moderation. J. Health Psychol. 22(14) (2017) 1799-1807 DOI: 10.1177/1359105316636950

[19] M. Çavuş, A. Gökçen. Psychological capital: definition, components and effects. Brit. J. Edu, Soc. Behav. Sci. 5(3), 2015, 244-255 DOI: $10.9734 /$ bjesbs/2015/12574

[20] S.A. Schulz, K.W. Luthans, J.G. Messersmith. Psychological capital: A new tool for driver retention. Int. J. Phys. Distrib. Logist. Manag. 44 (2016) 621-634. DOI: 10.1108/IJPDLM06-2013-0174 
[21] M. Sabokro, S.M. Tabataba, B. Fallahi. Explanation of work -family conflict through psychological capital among nurses. Iran. J. Nurs. Res. 13(2) (2018) DOI: 10.21859/ijnr130211

[22] F. Luthans, B. J. Avolio, J. B. Avey, S. M. Norman. Positive psychological capital: Measurement and relationship with performance and satisfaction. Pers. Psychol. 60(3) (2007) 541-572. DOI: 10.1111/j.17446570.2007.00083.x

[23] M. Kim, C. Windsor. Resilience and work-life balance in first-line nurse manager. Asian Nurs. Res. 9(1) (2015) 21-27. DOI: 10.1016/j.anr.2014.09.003

[24] B. Bande, P. Fernández-Ferrín, J. A. Varela, F Jaramillo. Emotions and salesperson propensity to leave: The effects of emotional intelligence and resilience. Ind. Mark. Manag. 44 (2015) (142-153) DOI: 10.1016/j.indmarman.2014.10.011

[25] J. J. Lanz. Examining the impact of resilience on work stress and strains in nurses. Dissertation Abstracts International: Section B: The Sciences and Engineering 77(6) 2015, DOI: 10.25148/etd.FIDC000067

[26] D. Macphee, E. Lunkenheimer, N. Riggs. Resilience as regulation of developmental and family processes. Fam. Relat. 64(1) (2015) 153-175 DOI: $10.1111 /$ fare. 12100

[27] J. Lee, S. Kim. Work-family conflict of women entrepreneurs in Singapore. Women in Manag. Rev. 16(5) (2001)

[28] Artiawati. Kerja-keluarga pada jurnalis di Jawa dan Bali (Model konflik kerja-keluarga dengan ideologi peran gender, beban peran berlebih, dukungan sosial, dan kepribadian sebagai anteseden; rasa bersalah dan kesejahteraan psikologis sebagai konsekuensi) Disertasi. 2012, pp. 3-27. 